gast's series of election studies were among the best compilations of aggregate election data available at the time and were widely admired and utilized by political scientists and journalists. He also provided staff research assistance in the drafting of the national party platforms throughout the 1960s.

Bill Pendergast graduated from the University of Notre Dame, where he received his bachelor's and master's degrees in political science. He also received a licentiate in political science from the University of Louvain in Belgium prior to completing his doctorate in political science at the University of Chicago. He taught political science and history at the U.S. Naval Academy from 1946 to 1956 and also taught courses in government and international relations at Catholic University and Johns Hopkins University.

A native of Bridgeport, Connecticut, Prendergast arrived in the Washington area after serving in the Army and the Office of Strategic Services during World War II. He was discharged as a captain. In 1956, he fulfilled a lifelong dream by running for Congress from Maryland, albeit unsuccessfully.

After the election of President Richard Nixon in 1968, Bill Prendergast was named a special assistant to the secretary of defense; three years later he was named defense advisor to the U.S. mission to NATO in Brussels, Belgium. He worked for the ACTION program of the Office of Economic Opportunity until 1976. Subsequently, he was a consultant and lobbyist for a number of trade groups.

During his long career, he produced many notable research monographs for the Republican party organizations he served. He published a number of articles on politics for Commonweal, America, and American Political Science Review and he wrote for several organizations, including the American Enterprise Institute. One of his proudest achievements was publishing The Catholic Voter in American Politics in June, just a few months before his death.

He was a member of St. John's Catholic Church in McLean, the Capitol Hill Club, the Notre Dame Club of Washington, the American Political Science Association, the American Catholic Historical Asso- ciation, and the Eisenhower World Affairs Institute.

Bill Prendergast pioneered the use of statistics for policy research, and was a master at presenting results in such a way as to make them understandable to average citizens, candidates, campaign managers, and journalists. He was widely admired in political circles and, at one point, officers of the Democratic National Committee successfully sought his advice and assistance in focusing and strengthening their own research efforts.

Those of us who knew and worked with Bill Prendergast during his years in Washington were always struck by the breadth of his knowledge of politics and his ability to apply it. During campaign periods, he was often on the telephone for entire days at a time answering questions and explaining results. $\mathrm{He}$ was generous with his knowledge and believed that the results of research, even research done under party auspices, should be made available and disseminated to those who needed it.

Bill Prendergast is survived by his wife of 57 years, Mary, two sons, one daughter, and eleven grandchildren.

Robert J. Huckshorn Florida Atlantic University

\section{Peter Snow}

Peter Snow died on November 16, 1999. For more than 30 years, he served on the faculty of the University of Iowa, having been recruited in 1962, the year before he completed his Ph.D. at the University of Virginia. Many who read this remembrance will already know of Peter's scholarship: the books on Latin American Radicalism, on political forces in Argentina, on charismatic bonding, and on Argentine government, in addition to the numerous published research papers. However, few readers will know much about his life, so that will be our focus.

Peter was born in Boulder, Colorado, in 1933. Years later he began his collegiate studies-though, as he would be the first to admit, "studies" is probably the wrong word-in that same community. Sampling the many delights of college life left Pe- ter little time to attend to such incidentals as attending classes and writing term papers. Soon, as it often did in the 1950s, the Army beckoned, and Peter served his country for two years in Austria before returning to college, this time at Texas Tech, with a new sense of academic purpose. He received his B.A. and M.A. in political science from Tech before moving to Virginia to pursue doctoral studies in Latin American politics.

At Iowa, Peter moved very quickly through the academic ranks, becoming a full professor only seven years after completing his Ph.D. While traveling along his professional path (indeed, throughout his entire life) he displayed a striking degree of self-reliance. After deciding in the late 1960s that he needed to know some statistics, he taught himself the subject up through the intermediate level, publishing an innovative paper on the application of cumulative scaling to measures of political development. When using computer applications to process data became standard practice among younger scholars, Peter taught himself how to program in FORTRAN and then wrote a program to do regression analysis. Of course, he quickly brought his new knowledge to bear upon his research and earned a welldeserved reputation for methodological innovation in Latin American political studies.

Peter held a lifelong devotion to baseball and believed the Brooklyn Dodgers to be the greatest actualization of the sport's mythic promise. He was himself a semi-professional pitcher before he found his way into graduate studies. In addition, Peter was a phenomenal poker player, as Iowa graduate students and faculty from the 1960 s will remember. $\mathrm{He}$ won so routinely in games with these innocents (who were also his friends) that, after a time, he concluded he could no longer continue taking their money in good conscience. So, except for games played against casino professionals, he set poker aside and turned his talents to creating crossword puzzles. His puzzles soon began appearing in publications around the world, including The New York Times. On one occasion, the Times puzzle editor took the very rare step of soliciting Peter 
to create a particular holidaythemed puzzle for the Sunday magazine. Peter also played an excellent game of golf and, for a time, did serious creative work behind the footlights in community theater.

Both of us writing this remembrance worked with Peter as coauthors. Having him critique or analyses and prose could be slightly deflating, but we always finished with better products when we attended to his concerns. Both of us also knew him as a wonderful friend and colleague. Only the latter writer, however, had Peter as teacher and mentor: a rich experience that convinced him to become a specialist in Latin American politics.

Peter was part Cherokee and his Native American heritage meant a good deal to him. For that reason, he established through the American Indian College Fund a scholarship for students wishing to study political science. Contributions may be sent to the Peter G. Snow Scholarship, c/o Marge, American Indian College Fund, PO Box 19019, NY, NY 10277-0386.

Survivors include a son, Steven (who teaches political science at Wagner College); a daughter-in-law, Cheryl Wheeler; and a newborn granddaughter, Ailie Anne.

Those whose lives Peter touched-family and friends, students and colleagues-will greatly miss this very special man.

Douglas Madsen

University of lowa

Luigi Manzetti

Southern Methodist University

\section{Lloyd M. Wells}

Our colleague of many years, Lloyd Manning Wells, Professor Emeritus of Political Science at the University of Missouri, Columbia, passed away on January 4, 2000, after a lingering illness. He was 80 years old.
Lloyd was born in the small community of Clever, Missouri, in 1919. He was drafted into the Army in June of 1941 and, after attending OCS, was commissioned as a Second Lieutenant with the 1st Armored Division. Lloyd saw action in North Africa, Italy, and Germany. He was awarded the Combat Infantry Badge, the Purple Heart with two oak clusters, and the Bronze Star. He left the Army as a First Lieutenant and enrolled at Southwest Missouri State College, from which he received a B.A. in 1948. He received an M.A. from the University of Missouri in 1950 and a Ph.D. from Princeton University in 1955. While a student at Princeton, Lloyd worked for the Legislative Reference Bureau of the New Jersey State Legislature. He was a member of the Southern Methodist University faculty from 1955 to 1958 and served on the University of Missouri faculty from 1958 until he retired in 1985.

Lloyd's research centered on the Supreme Court and the bureaucracy. He coauthored The Supreme Court and Public Opinion and his articles appeared in Social Science Quarterly and Public Administration Review as well as several anthologies.

We remember him best as a teacher, administrator, and colleague. He taught courses ranging from freshman-level American government to advanced undergraduate courses and graduate seminars in public administration. He received praise for his teaching, for his ability to stimulate thought, and for his gentle sense of humor. He dealt with students in class and individually in a sympathetic and encouraging manner.

At one time or another, he held every administrative position in the department and carried out all assignments with aplomb. As chair from 1967 to 1970 , Lloyd was sensitive to the needs of faculty to exercise their discretion in teaching and research. He was the type of academic administrator who believed that a community of scholars could behave in a collegial and responsible way, and he conducted himself in such a manner as to draw those values out in others.

His consecutive terms as graduate director and chair coincided with a considerable expansion of faculty and graduate students in the department. Lloyd conducted himself as a faculty member, as graduate director, and as department chair with integrity and fairness. He employed his good judgment and mediation skills to help members of departmental committees work their way through potentially divisive problems. Withal, there was his clever wit to enliven meetings.

From our personal perspectives, he performed his greatest service by easing the passage from a smaller to a larger program for young faculty and graduate students orienting themselves to the teaching profession and discipline. His graduate students from that era have continued to refer to Lloyd simply as "the chairman" when they have gotten together in later years.

He is survived by his wife of fifty years, Carolyn, and three grandchildren. A son, Randall, preceded him in death.

Lloyd will be missed by his family, his colleagues, and his students. However, we are content that his was truly a life worth living.

Dean L. Yarwood

University of Missouri, Columbia

David M. Wood

University of Missouri, Columbia 